Int. J. Dev. Biol. 56: 135-142

doi: $10.1387 / \mathrm{ijdb} .123505 \mathrm{lr}$

\title{
Stem cells and neural signalling: the case of neoblast recruitment and plasticity in low dose $\mathrm{X}$-ray treated planarians
}

\author{
LEONARDO ROSSI, PAOLA IACOPETTI and ALESSANDRA SALVETTI* \\ Department of Human Morphology and Applied Biology, University of Pisa, Italy
}

\begin{abstract}
Planarians (Platyhelminthes) possess an abundant population of adult stem cells, the neoblasts, capable to give rise to both somatic and germ cells. Although neoblasts share similar morphological features, several pieces of evidence suggest that they constitute a heterogeneous population of cells with distinct ultrastructural and molecular features. We found that in planarians treated with low X-ray doses (5 Gy), only a few neoblasts survive. Among these cells, those located close to the nervous system activate an intense proliferation program and migrate to reconstitute the whole complex neoblast population. This phenomenon is inhibited by the substance $\mathbf{P}$ receptor antagonist spantide, and accompanied by the up-regulation of a number of genes implicated in neuronal signalling and plasticity, suggesting that signals of neural origin modulate neoblast proliferation and/or migration. Here, we review these findings and the literature available on the influence of the nervous system on stem cell activity, both in planarians and vertebrates, and we propose $\mathbf{5 ~ G y - t r e a t e d ~ p l a n a r i a n s ~ a s ~ a ~ u n i q u e ~ m o d e l ~ s y s t e m ~ t o ~ s t u d y ~ t h e ~ i n f l u e n c e ~ o f ~ n e u r a l ~ s i g n a l - ~}$ ling on stem cell biology.
\end{abstract}

KEY WORDS: planarian, neoblast, adult stem cell, nervous system, neurotransmitter

\section{Introduction}

Stem cells and their potential therapeutic applications in tissue replacement represent a foremost focus of medical research. However, gaps in our knowledge must be filled to fully exploit stem cell therapeutic potential for the treatment of several devastating diseases, like neurodegenerative and cardiovascular diseases or muscular dystrophy. Among such knowledge gaps, a problematic central issue is the extrinsic control exerted in vivo by the microenvironment surrounding the stem cells, the so-called niche, on cell self-renewal, proliferation and differentiation. The niche regulates stem cell activity through several mechanisms, namely cell-cell and cell-matrix adhesion, cell-cell signalling via both membrane and secreted factors, enzymatic modifications of the extracellular matrix, etc. The niche modulates stem cell function under conditions of physiological challenge, and constitutes a suitable target for novel therapies, not only to enhance the regenerative ability of normal stem cells, but also to reduce the malignant potential of cancerous ones (Scadden, 2006).

Freshwater planarians (Platyhelminthes) provide a suitable model system for studying stem cell-niche interactions in vivo.
Indeed, planarians possess a population of pluripotent adult stem cells, the neoblasts, capable to give rise to both somatic and germ cells (Rossi et al., 2008; Wenemoser and Reddien, 2010). Thanks to the neoblasts, planarians exhibit extraordinary regenerative capabilities: each small body piece is able to rebuild a complete organism, with a functional brain, within a week after amputation. This advantage, coupled with the successful application of molecular, cellular and genomic approaches, as well as the possibility to perform loss of function studies by the RNA interference (RNAi) technique, makes planarians a sound model system for in vivo investigations on stem cell biology and regeneration processes (Salò et al., 2009; Sánchez Alvarado, 2007; Rossi et al., 2008; Shibata et al., 2010; Gentile et al., 2011; Aboobaker, 2011). Moreover, the possibility to selectively eliminate neoblasts by X-rays allows to directly compare stem cell less-animals to wild-type planarians (Rossi et al., 2008).

In this paper, we review the available data on planarian neoblasts and a possible role of the nervous system in regulating neoblast

Abbreviations used in this paper: $\mathrm{BM}$, bone marrow; $\mathrm{CB}$, chromatoid bodies; Gy, gray (unit of absorbed ionizing radiation); HSPC, hematopoietic stem and progenitor cell.

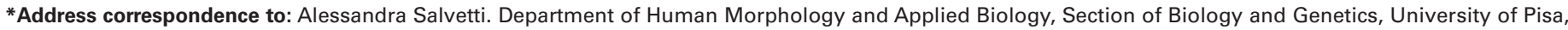
Via Volta 4, 56126 Pisa, Italy. Tel: +39-50-221-9108. Fax: +39-50-221-9101. e-mail: a.salvetti@ biomed.unipi.it - web: http://salvetti.med.unipi.it/Home.html
} 
proliferation and migration, that is, in defining a niche, and we compare such knowledge with the evidence on the role of neural factors in defining adult stem cell niches in vertebrates.

\section{Neoblasts}

The term neoblast, originally used to describe an annelid cell type (Randolph, 1892), is historically used to define an abundant population of dividing cells sharing a similar morphology and representing about $20-30 \%$ of planarian cells. At the ultrastructural level, neoblasts are small cells with a diameter of 5-10 $\mu \mathrm{m}$, rounded or pear-shaped, with a high nucleus/cytoplasm ratio and an undifferentiated cytoplasm with chromatoid bodies (CB) (Fig. $1 \mathrm{~A})$. CBs are electron dense perinuclear granules composed of RNA and proteins that decrease in number and size during cell differentiation, and, for this reason, are thought to be required for neoblast self-renewal and proliferation (Shibata et al., 2010). In support of this hypothesis, a set of RNA-binding factors has been found to be necessary to maintain neoblast pluripotency (YoshidaKashikawa et al., 2007; Rouhana et al., 2010), and silencing of Smed-SmB, a homolog of a member of the LSm protein family, results in loss of $\mathrm{CBs}$ organization and severe neoblasts proliferation failure (Fernandéz-Taboada et al., 2010). Moreover, Solana and colleagues (2009) demonstrated that a tudor homolog, Spoltud-1, is a component of $\mathrm{CBs}$ and is required for neoblast maintenance.

Neoblasts are involved in the formation of the blastema, an unpigmented structure where missing body parts are regenerated, in growth-degrowth processes and in tissue homeostasis (Rossi et al., 2008). Neoblasts are spread in the parenchyma, a mesenchymal tissue that fills the space between the epidermis and the organs, and are not present in the most anterior part of the head and in the pharynx. In Dugesia japonica, neoblasts are also clustered in two dorso-lateral lines and along the body midline, as it can be visualized using general cell proliferation markers such as DjMCM2 and DjPCNA (Salvetti et al., 2000; Orii et al., 2005) (Fig. 1B).

Neoblasts are the only proliferating cells in asexual planarians chiefly defined, at the molecular level, only on the basis of the expression of cell division markers, and aspects of their cycling activity have been elucidated by BrdU labelling (Newmark and Sánchez Alvarado, 2000). However, by analogy to other systems, neoblasts likely comprise both stem cells and transient progenitors, and the identification of molecular markers to unequivocally subdivide "neoblasts" into true stem cells and progenitor populations would appear as a key prerequisite for putting planarian stem cell research en par with other systems. In the last years, the breakthrough of new methodologies and genome sequencing (http://genome.wustl.edu/genomes) has led to the identification of several genes involved in neoblast maintenance, proliferation and differentiation and neoblast research has received a significant boost from new approaches (Sánchez Alvarado, 2007; Rossi et al., 2007; Eisenhoffer et al., 2008; Salò et al., 2009; Abril et al., 2010; Blythe et al., 2010; Hayashi et al., 2010; Shibata et al., 2010; Aboobaker, 2011; Adamidi et al., 2011; Fernández-Taboada et al., 2011; Gentile et al., 2011; Qin et al., 2011), paving the way to the classification of neoblasts in subpopulations that might show different self-renewal/differentiation potential. Heterogeneity among neoblasts has been suggested by the identification of molecular markers, such as DjPiwi-1, a $D$. japonica homologue of the Drosophila Piwi gene, that is expressed in a subpopulation
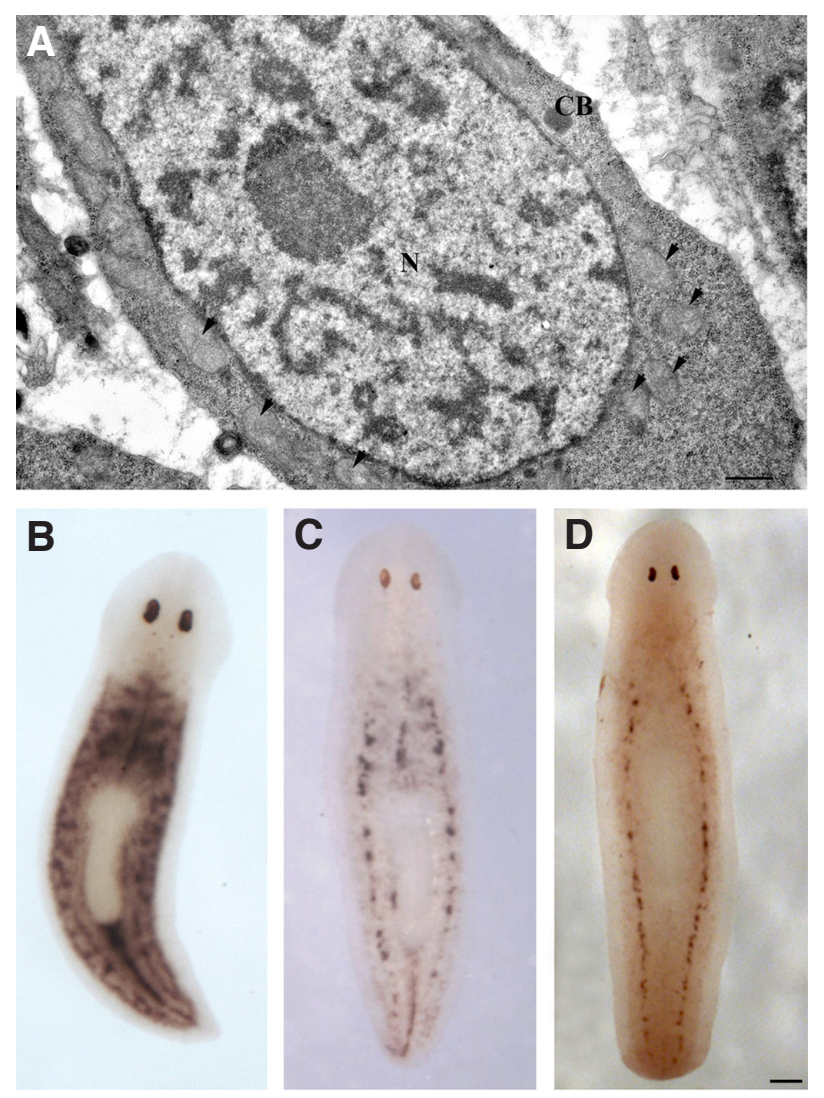

Fig. 1. Neoblasts. (A) Electron micrograph depicting a neoblast. The arrowheads indicate some mitochondria. CB: chromatoid body; N: nucleus. Scale bar: $100 \mathrm{~nm}$. (B-D) Expression of the neoblast marker DjMCM2 visualized by whole mount in situ hybridization in an untreated organism (B) and in 5 Gy treated planarians 1 day (C) and 3 days (D) after irradiation. Scale bar: $500 \mu \mathrm{m}$.

of neoblasts localized along the dorsal body midline (Rossi et al., 2006). Sato and coworkers (2006) identified a nanos-related gene that is expressed in a subset of neoblasts localized in two dorsal lateral lines and two ventral spots, the presumptive germline stem cells. The presence of different neoblast subpopulations is also supported by cytofluorimetrical and ultrastructural analyses, that led to identify two different $\mathrm{X}$-ray sensitive cell fractions (X1 and X2), containing different types of neoblasts (Hayashi et al., 2006; Higuchi et al., 2007). The X1 fraction is highly enriched in type A neoblasts (renamed type 1, Shibata et al., 2010), characterized by large cell size, a euchromatin-rich nucleus and several chromatoid bodies in their cytoplasm (Higuchi et al., 2007). It has been suggested that this fraction mainly contains proliferating neoblasts, since $\mathrm{X} 1$ cells express high levels of cell cycle markers such as DjMCM2 and DjPCNA (Hayashi et al., 2006). The X2 cell fraction mainly contains type $B$ neoblasts (renamed type 2 , Shibata et al., 2010), with a smaller cell size than cell type A, a heterochromatinrich nucleus and few chromatoid bodies (Higuchi et al., 2007). The X2 fraction also includes differentiating and differentiated cells (Higuchi et al., 2007).

Although it is possible that type 1 and 2 neoblasts are the same cell type in different phases of the cell cycle, on the whole the data described above suggest that neoblasts are not a homogeneous population of cells, but rather a compound of different subpopula- 
tions with different morphological features and expressing different sets of genetic markers.

Further evidence in support of neoblast heterogeneity comes from planarians treated with low X-ray doses, such as $5 \mathrm{~Gy}$, in which at least three subpopulations of neoblasts with different levels of radiotolerance can be identified (Salvetti et al., 2009). The neoblasts clustered along the dorsal lateral lines are more radioresistant than those clustered along the body midline (Fig. 1D). Spread neoblasts are the most radiosensitive cells, as the majority of them disappear 1 day after treatment with the 5 Gy dose (Fig. 1C). We suggest that radiosensitive spread neoblasts are the dividing transit cell population, and their low radiotolerance might be ascribed to a higher cycling rate.

5 Gy-treated animals do not die and can regenerate, as the dramatic reduction of neoblasts is rapidly compensated by a few radioresistant $D$ jMCM-2-positive cells that proliferate and repopulate the whole planarian body (Salvetti et al., 2009). Similarly, Wagner and coworkers (2011) demonstrated the existence of rare radioresistant smedwi-1-positive neoblasts, capable to repopulate $S$. mediterranea after 17,5 Gy exposure. By combining low irradiation doses and single-cell transplanting, they provided evidence that radioresistant smedwi-1-expressing neoblasts have clonogenic capability and are able to transform the irradiated recipient into a genetic clone of the donor by replacing all cells, thus demonstrating that at least some cells, among the neoblast population, are pluripotent stem cells.

Despite the boost from new approaches and the the breakthrough of new methodologies, much remains to be understood about neoblasts and their biology. For example, what is the percentage of pluripotent neoblasts? Is the stem cell compartment hierarchically organized? What signals regulate neoblast biology?

\section{Neoblasts and the nervous system}

It has been proposed that differentiated cells surrounding neoblasts might control neoblast biology and regeneration, by releasing signal molecules recognized by neoblast receptors (Baguñà et al., 1989; Agata, 2003). Indirect experiments suggest that the nervous system might contribute to the neoblast niche, thus regulating neoblast biology, as well as playing a morphogenetic action.

The planarian nervous system consists of two anterior ganglia connected with two ventral nerve cords (Fig. 2A). Several neuronal cell subtypes have been characterized in planarians, with respect to the neurotransmitter that they produce, for example dopamine
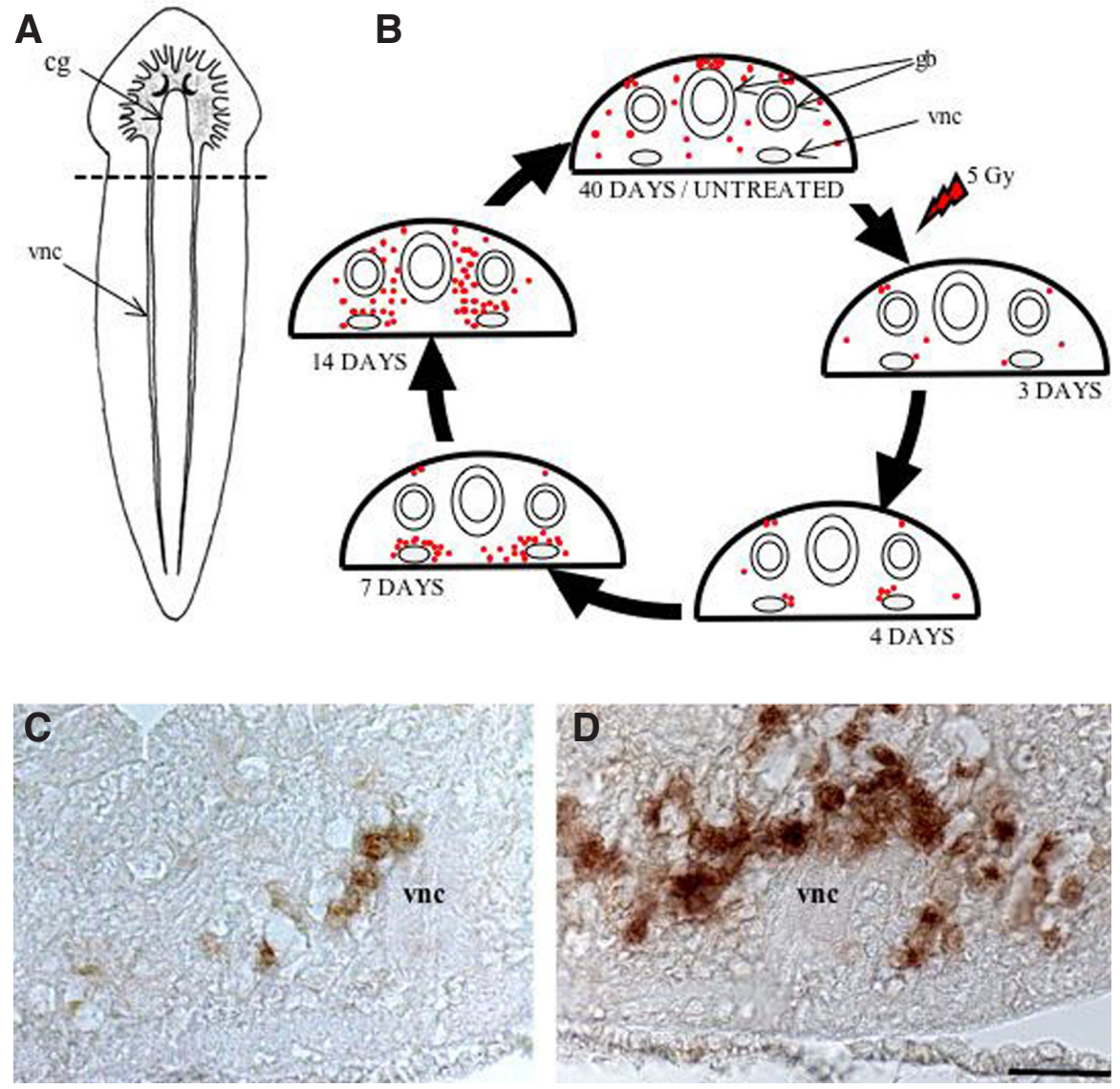

Fig. 2. Neoblast repopulation after $\mathbf{5}$ Gy irradiation. (A) Diagram of a planarian, the central nervous system is schematically represented. Dashed line indicates the level of sections depicted in B-D. (B) Scheme depicting DjMCM2- positive cell distribution in transverse sections after 5 Gy irradiation. (C,D) DjMCM2 expression visualized by in situ hybridization in a transverse section 4 days (C) or 7 days (D) after irradiation. cg: cephalic ganglia; vnc: ventral nerve cords; gb: gut branch. Scale bar: $50 \mu \mathrm{m}$.
(DA), serotonin (5-HT), GABA and octopamine (Nishimura et al., 2007a,b; 2008a,b). Moreover, peptidergic neurons such as allatostatin-, substance P-, GYRFamide-, somatostatin (SRIF)and met-enkephalin-producing neurons have been identified (Bautz and Schilt, 1986; Cebrià, 2008). Moreover, 51 genes predicted to encode more than 200 peptides have been isolated and characterized in S. mediterranea. About $85 \%$ of these prohormone genes have been found to be expressed in the central nervous system (Collins et al., 2010).

The dependence of regeneration of lost body parts on concomitant nerve regeneration is widely conserved in phylogeny, being observed not only in various contexts in vertebrates but also in echinoderms and annelids (Brockes and Kumar, 2008).

Conflicting evidence for and against a role of the nervous system as a planarian stem cell niche exists. A number of classical studies indicate that removal of the nervous system inhibits regeneration in several species. The number of neurosecretory cells increases significantly during regeneration, and an accumulation of neurosecretory granules has been described six hours after amputation (Cebrià, 2007). Friedel and Webb (1979) showed that a neurosecretory fraction, isolated from regenerating planarians, significantly stimulated the number of proliferating cells. It has been proposed that neuropeptides control neoblast biology, both promoting neoblast proliferation, as demonstrated for neuropeptide $\mathrm{F}$ and substance $\mathrm{K}$, and reducing mitotic activity, as demonstrated for somatostatin-like peptide (Bautz and Schilt, 1986; Hori and Kishida, 2003; Kreshchenko et al., 2008). The influence of the 
nervous system on neoblast proliferation has also been suggested by Baguñà and coworkers (1989) who demonstrated a mitogenic role for substance $\mathrm{P}$ in planarians. Moreover, serotonin has been found to stimulate cell proliferation, noradrenaline and propranolol (a $\beta$-adrenergic antagonist) are known to modify the regeneration rate, and specific dopamine inhibitors reduce the regeneration rate (Franquinet, 1979). Despite these intriguing data, the role of neurotransmitters in the regulation of neoblast proliferation and regeneration is still an open question. For example, the knockdown of tyrosine hydroxylase in $D$. japonica, which is accompanied by an extensive loss of dopamine, does not inhibit regeneration (Nishimura et al., 2007b). On the other hand, a large scale screening identified 5 genes, expressed in the planarian nervous system, whose silencing by RNA interference inhibits regeneration (Reddien et al., 2005); silencing of one of them, NB43.2h, resulted in a reduction of neoblast proliferation in the blastema (Brockes and Kumar, 2008).

Interestingly, it has frequently been observed that genes expressed in neoblasts, encoding for putative RNA-binding proteins (Shibata et al., 1999; Salvetti et al., 2005; Guo et al., 2006; Yoshida-Kashikawa et al., 2007; Solana et al., 2009; FernandézTaboada et al., 2010), as well as Smed-CHD4 (Scimone et al., 2010) and Smedinx-11 (Oviedo and Levin, 2007), encoding a putative chromatin remodelling protein and a gap junction factor, respectively, are also expressed in fully differentiated brain neurons. Yoshida-Kashikawa and coworkers (2007) demonstrated that the DjCBC-1 protein, a homolog of the DEAD box RNA helicase gene, is expressed in neoblast CBs and also in neural CB-like structures, suggesting that post-transcriptional regulation is a common mechanism in somatic cells. Although there is not a clear explanation for this phenomenon, it might be speculated that the concomitant expression of these genes in neoblasts and neurons might regulate in a coordinate way the expression of cell type specific factors that finally promote a joined response, such as an increase or decrease of neoblast proliferation/differentiation.

Aneural-induced neoblast proliferation has also been suggested in $D$. japonica by the evidence that neoblast repopulation in 5 Gy-treated animals started ventrally from a few DjMCM2-positive cells adjacent to the ventral nerve cords (Salvetti et al., 2009). Although the 5 Gy dose dramatically reduced neoblast number, surviving neoblasts were detectable throughout the body 3 days after irradiation. In the following days, the number of neoblasts associated with the nerve cords increased, producing large cell clusters that could be observed 1 week after irradiation (Salvetti et al., 2009) (Fig. 2). Notably, neurosecretoty cells have been described all along the nerve cords (Cebrià, 2007). In subsequent days, these radioresistant cells and/or their progeny migrated to the dorsal side of the planarian body, thus re-establishing the neoblast system (Fig. 2B). In 5 Gy-treated animals, clusters of neoblasts expressing the cell cycle markers DjMCM2 and DjPCNA were also present anterior to the eyes (Fig. 3). We exclude that these clusters of cells are quiescent neoblasts that reactivate proliferation following 5 Gy irradiation, since this region is normally devoid of neoblasts (Rossi et al., 2008). A more plausible hypothesis is that these anterior cells derived from the migration of neoblasts from a region posterior to the eyes, whose number in 5 Gy irradiated animals, starting from the $10^{\text {th }}$ day after irradiation, was greater than in untreated animals. Later on, neoblast density decreased to pre-treatment levels, and neoblast cell clusters anterior to the eyes disappeared (Salvetti et al., 2009).

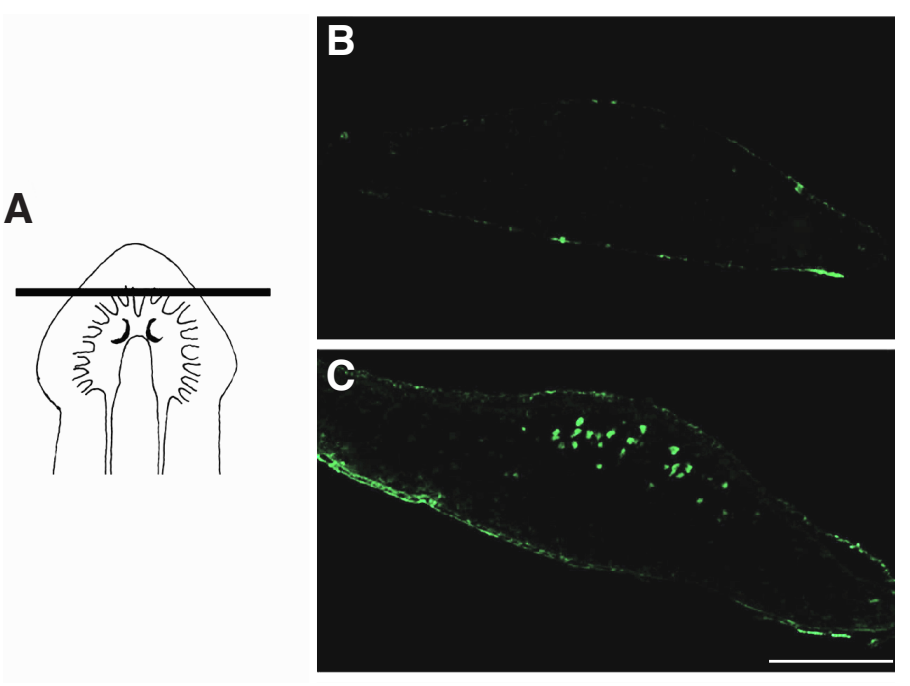

Fig. 3. Detection of proliferating cells in the cephalic region anterior to planarian eye spots. (A) Diagram of the planarian head, the nervous system is schematically represented. The line indicates the level of sections depicted in B and C. (B,C) Distribution of DjPCNA expressing neoblasts visualized by immunofluorescence in an untreated control (B) and in a 5 Gy-treated animal 11 days after irradiation (C). Scale bar: $200 \mu \mathrm{m}$.

The idea of a neural-induced cell proliferation is also supported by the evidence that spantide, an antagonist of the neuropeptide substance $P$ that is a potent mitogen in planarians (Baguñà et al., 1989), drastically reduced the number of mitoses in 5 Gy animals, suggesting that substance $\mathrm{P}$ might affect neoblast proliferation in irradiated animals (Salvetti et al., 2009). A release of substance $P$ is consistent with the observed up-regulation of factors of the mitogen-activated protein (MAP) kinase pathway in 5 Gy-treated animals (Rossi et al., 2007). The substance $P$ receptor has indeed been shown to signal through the MAPK pathway (Salvetti et al., 2009).

Microarray analysis of gene expression upon 5 Gy irradiation also revealed the up-regulation of several genes encoding enzymes involved in the metabolism of neurotrasmitters (Rossi et al., 2007). Moreover, a homolog of pushover (push), which has been implicated as downstream target of Amn or PACAP neuropeptides, and that controls perineural glial growth in Drosophila (Yager et al., 2001), is up-regulated after 5 Gy treatment, together with a PACAP homolog (Rossi et al., 2007). To focus our attention on genes specifically involved in neoblast reactivation after 5 Gy treatment, we restricted the supervised analysis II presented by Rossi and coworkers (2007), by comparing the transcriptional profile of 5 Gy-treated animals 4 days after the treatment, the time when neoblasts reappear ventrally, to that of controls (not irradiated). By this approach, we identified some up-regulated genes (Fig. 4). Some of these genes have already been characterized in planarians, such as DjCBC-1 (Yoshida-Kashikawa et al., 2007) and Djwnt-A, the planarian homolog of wnt, which is expressed in the posterior region of the wild-type planarian brain (Kobayashi et al., 2007). In addition, other interesting genes were found upregulated, such as the homologs of RHO1 GTPase, cathepsin B, dynactin subunit 2, twinfilin-1, kallikrein, Septin 11. These genes are not exclusively expressed in neurons. However, findings indicate that these molecules play roles in neuronal plasticity (Billuart et al., 2001; Kwinter et al., 2009; Wang et al., 2010; Li et al., 2009; Winge 
et al., 2008; Yousef et al., 2003). To date, we are not aware of any data about the role and expression of these genes in planarians.

Wagner and coworkers (2011) irradiated S. mediterranea at $17,5 \mathrm{~Gy}$, a dose at which very rare neoblasts survived, in a small percentage of the animals; survivor cells proliferated to form clusters that consistently originated ventrally in the animals. Such rare cells were not always adjacent to the nervous system, due to the much higher X-ray dose used by Wagner and coworkers that destroyed almost all smedwi-1-positive neoblasts, including those associated to the nerve cords. In this scenario, neural signals might activate the proliferation of more distant susceptible cells.

\section{Stem cells and neural signalling in vertebrates}

The role of the nervous system in the regulation of stem cell proliferation and motility in vertebrates is a still poorly explored field, apart from a few exceptions.

The nervous system plays an essential role during the regeneration of salamander limbs: nerve regrowth is required for the proliferation of blastemal stem cells, and denervation induces limb regeneration failure (Brockes and Kumar, 2008). It has been found that the growth factor nAG, whose expression is regulated by nerves, mediates nerve-dependent proliferation in the blastema and is sufficient to rescue denervated blastema and promote regeneration (Kumar et al., 2007).

Signals of neural origin have been shown to play a pivotal role in regulating adult hematopoietic stem cell proliferation and housing, and very recent data indicate that this is likely the case also for intestinal stem cells (see below for references), suggesting that the nervous system might control stem cell niches in several different organs and tissues of higher vertebrates.

Hematopoiesis represents the best studied example of interplay between neural signals and stem cell regulation in vertebrates. The innervation of the hematopoietic stem and progenitor cell (HSPC) niches, namely the bone and bone marrow (BM) microenvironment, has a very important role in regulating both proliferation and mobilization of HSPCs, as suggested by the observation that individuals with spinal cord injury show hematopoietic suppression in the bones below the region of injury (Spiegel et al., 2008). Notably, immature human CD34+ progenitors dynamically express dopamine and $\beta$-adrenergic receptors in a hierarchical orientation, and in response to stimulation with myeloid cytokines such as Granulocyte-Colony Stimulating Factor (G-CSF). Receptor levels are higher in the more primitive CD34+/CD38 -llow cells, enriched with repopulating HSCs, and lower in the committed CD34 $/$ CD38 ${ }^{+}$progenitors, followed by high expression in certain lineages of mature leukocytes, indicating a possible direct role for neurotransmitters in the regulation of HSPC migration, proliferation, and development (Spiegel et al., 2008). G-CSF-induced mobilization of murine progenitor cells requires peripheral adrenergic signals: norepinephrine signalling controls G-CSF-induced osteoblast suppression, HSPC mobilization and downregulation of BM stromal-derived factor-1 (SDF-1), a chemokine attracting and promoting survival and development of both hematopoietic and stromal stem cells (Katayama et al., 2006). Circadian fluctuations of SDF-1 levels controlled by the sympathetic nervous system, represent one of the mechanisms underlying circadian oscillations of HSPC release (Mendez-Ferrer et al., 2008). Sympathetic signals from the nervous system activated by circadian rhythms or stress conditions control HSPC motility and development also indirectly, by way of bone remodelling processes. Osteoblastic cells are involved in HSC lodgement, self-renewal and function, while bone resorbing osteoclasts regulate bone turnover and progenitor cell detachment and release from the BM; the balance toward osteoclast activation and osteoblast suppression, in turn, is known to be regulated by signals from the nervous system, particularly beta-adrenergic signals (Kollet et al., 2012; Lapidot and Kollet, 2010). Additionally, a $\beta 2$-adrenergic receptor agonist rescued the mobilization defects in mice deficient in dopamine $\beta$-hydroxylase and augmented G-CSF-induced HSPC mobilization. Moreover, norepinephrine and dopamine serve as chemoattractants, and exposure to these neurotransmitters increased the migration potential of immature human $\mathrm{CD} 34^{+}$cells. Thus, the sympathetic nervous system regulates the egress/housing of stem cells to their niches (Spiegel et al., 2008).

The $\mathrm{BM}$ is also innervated by sensory nerves secreting the neurotransmitter substance $P$; substance $P$ and neurokinin- $A$ (NK-A) are released into the BM cavity both by nerve fibers as neurotransmitters, and from resident BM cells, and interact with specific neurokinin receptors on BM resident cells, thereby affecting hematopoiesis with opposite effects on HSPC proliferation: substance $P$ stimulates proliferation of immature progenitors, whereas NK-A exerts suppressive effects. Immature CD $34^{+}$cells express receptors for several other neurotrasmitters, for example
Fig. 4. Eisen's clustering based on genes differentially regulated in 5 Gy X-ray treated planarians 4 days after irradiation and untreated controls. This analysis was based on 583 genes that passed filtering criteria (see Rossi et al., 2007) and the nominal significance level of univariate test was set to $p \leq 0.005$. 18 genes differentially expressed between 5 Gy X-ray treated planarians 4 days after irradiation and untreated controls were identified. These genes were clustered unvarying the sample grouping. A single gene, the putative planarian homologue of purinergic receptor $P 2 X$, is down-regulated in 5 Gy samples, 17 genes are up-regulated as a consequence of irradiation.

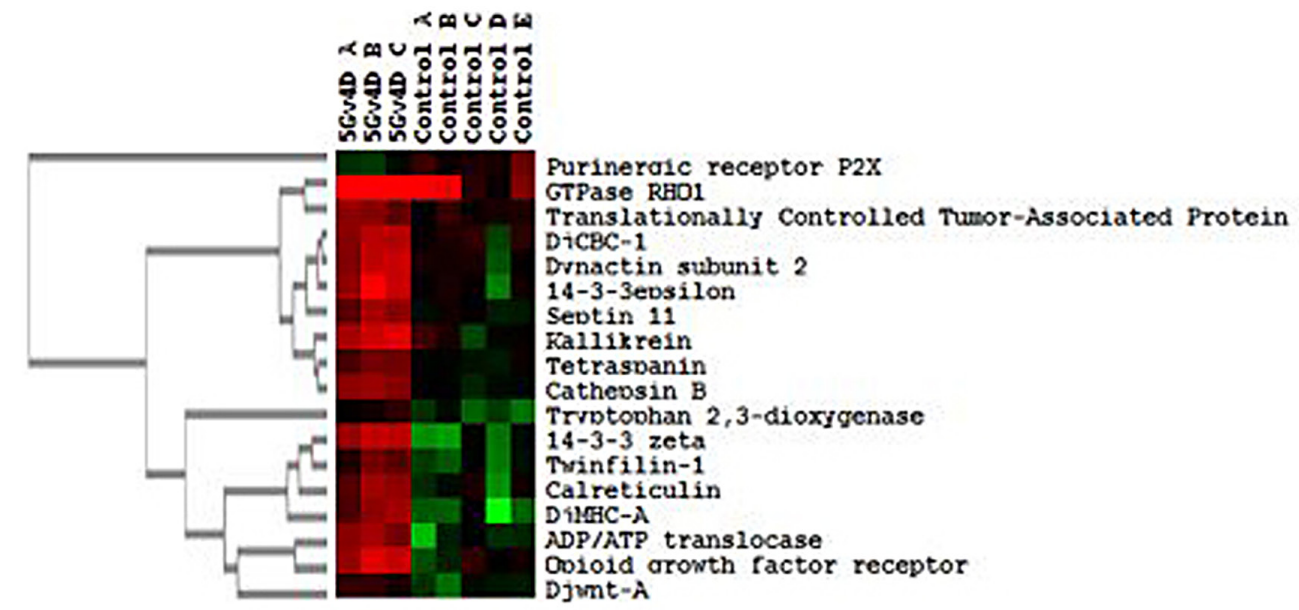


orexin, calcitonin gene-related peptide (CGRP), opioids, vasointestinal peptide (VIP), adenosine, $\gamma$-aminobutirate (GABA), and somatostatin (Kalinkovich et al., 2009). Recently, a novel function of SP as an injury-inducible messenger to mobilize bone marrow stem cells to the blood and engage them in tissue repair has been proposed (Hong et al., 2011). Moreover, SP has been found to alleviate $\gamma$-radiation-induced damage to mouse bone marrow stem cells and human mesenchymal stem cells via regulation of the apoptotic pathway (An et al., 2011).

A receptor of corticotrophin-releasing factor (CRF) and its related peptides urocortin 1, 2 and 3, CRF1, has been found expressed in the stem cells of the colonic crypts (Chatzaki et al., 2004). While the role of CRF or urocortin stimulation on colonic transit, motility, mucosal permeability, and inflammation is under intense investigation, to our knowledge a possible role of these neuropeptides in the regulation of colon stem cell proliferation has not been investigated.

A recent study in mice provides evidence for a nervous control of intestinal stem/progenitor cells in vivo: luminal capsaicin, which stimulates intestinal external axons, increased intestinal thymidine kinase (TK) activity, an indicator of cell renewal rate of the intestinal epithelium, $3 \mathrm{H}$-thymidine incorporation into DNA and number of BrdU labeled crypt cells. The observed capsaicin effects were nervously mediated, as they were attenuated by the anaesthetic lidocaine and by antagonists of four different neurotransmitters - muscarinic, nicotinic, neurokinin 1 and calcitonin gene related peptide (CGRP) receptors -, and abolished after degeneration of the extrinsic nerves (Lundgren et al., 2011). Immunoreactivity for M3 and M5 muscarinic receptors was detected on the intestinal stem/progenitor cells. The authors propose that the stem/progenitor cells are controlled by cholinergic nerves, which, in turn, are influenced by mucosal afferent neurons releasing acetylcholine and/or substance $P$ and/or CGRP. In mice lacking the capsaicin receptor, thymidine incorporation into DNA and number of crypt cells labeled with BrdU was lower than in wild type animals, suggesting that nerves are important also in the absence of luminal capsaicin (Lundgren et al., 2011).

\section{Conclusions}

The data reviewed in the present paper depict a pivotal role for signals released by the nervous system in the regulation of stem cell proliferation and housing, a role that appears to be conserved from planarians to higher vertebrates. This evolutionary conservation suggests that the strict interplay described between the vertebrate nervous system and HSPCs, or intestinal stem cells, might just represent the tip of the iceberg, and that neural signalling might contribute to stem cell niches in many other, or even all, adult vertebrate tissues and organs. Thus, this field, in our opinion, deserves much more attention, in that it might open new perspectives in stem cell biology and therapeutical applications. However, in complex organisms, such as vertebrates, it is very problematic to define exactly the effect of a given stimulus on stem cell maintenance, proliferation, commitment or migration, due to the difficult experimental accessibility of adult stem cells. The finding that planarian neoblasts seem to be under the control of neural signals is therefore particularly intriguing, since these organisms offer a number of advantages typical of an in vitro cell culture - that is, experimental accessibility, possibility to easily and rapidly interfere with gene expression, lack of ethical issues, etc. -, together with those of a living organism. However, direct evidence is necessary to definitely ascertain the contribution of the central nervous system in defining a neoblast niche and it is not known whether a specific anatomical location exists for neoblast along the nervous system, and whether other organs play a role in defining neoblast niches; for example the mesenchymal surface of the gut might be another important player in defining neoblast fate. Thus, the repopulation process that follows 5 Gy treatment might represent an ideal model system to test the effects of specific neuronal and non-neuronal signals on neoblast proliferation and housing. For example, the use of specific neurotrasmitter agonists or antagonists might allow to identify specific neuronal sub-types, involved in the control of neoblast biology, thus providing cues on the specific location of hypothetical anatomical niches along the ventral nerve cords. Finally, it cannot be excluded that the concept of niche might be extended to the entire planarian body, in which the interplay between stem cells and their differentiated progeny creates the dynamic system necessary for sustaining tissue turnover, regeneration and body size.

\section{Acknowledgements}

We wish to thank $C$. Ghezzani for technical assistance with images. This work was supported by the University of Pisa. We regret that we could not cite important publications due to space limitations.

\section{References}

ABOOBAKER AA (2011). Planarian stem cells: a simple paradigm for regeneration. Trends Cell Biol 21: 304-311.

ABRIL JF, CEBRIÀ F, RODRÍGUEZ-ESTEBAN G, HORN T, FRAGUAS S, CALVO B, BARTSCHERER K, SALÓ E (2010). Smed454 dataset: unravelling the transcriptome of Schmidtea mediterranea. BMC Genomics 11:731.

ADAMIDI C, WANG Y, GRUEN D, MASTROBUONI G, YOU X, TOLLE D, DODT M, MACKOWIAK SD, GOGOL-DOERING A, OENAL P, RYBAK A, ROSS E, ALVARADO AS, KEMPA S, DIETERICH C, RAJEWSKY N, CHEN W (2011). De novo assembly and validation of planaria transcriptome by massive parallel sequencing and shotgun proteomics. Genome Res 21: 1193-1200.

AGATA K (2003). Regeneration and gene regulation in planarians. Curr Opin Genet Dev 13: 492-496.

AN YS, LEE E, KANG MH, HONG HS, KIM MR, JANG WS, SON Y, YI JY (2011) Substance $P$ stimulates the recovery of bone marrow after the irradiation. $J$ Cell Physiol 226:1204-1213.

BAGUÑ̇̀ J, SALO E, ROMERO R (1989). Effects of activators and antagonists of the neuropeptides substance $\mathrm{p}$ and substance $\mathrm{k}$ on cell proliferation in planarians. Int J Dev Biol 33: 261-266.

BAUTZ A, SCHILT J (1986). Somatostatin-like peptide and regeneration capacities in planarians. Gen Comp Endocrinol 64: 267-272.

BILLUART P, WINTER CG, MARESH A, ZHAO X, LUO, L (2001). Regulating axon branch stability: the role of p190 RhoGAP in repressing a retraction signaling pathway. Cell 107: 195-207.

BLYTHE MJ, KAO D, MALLA S, ROWSELL J, WILSON R, EVANS D, JOWETT J, HALLA, LEMAY V, LAM S, ABOOBAKER AA (2010). A dual platform approach to transcript discovery for the planarian Schmidtea mediterranea to establish RNAseq for stem cell and regeneration biology. PLoS One 5: e15617.

BROCKES JP, KUMARA (2008). Comparative aspects of animal regeneration. Annu. Rev Cell Dev Biol 24:525-549.

CEBRIÀ F (2007). Regenerating the central nervous system: how easy for planarians! Dev Genes Evol 217:733-748.

CEBRIÀ F (2008). Organization of the nervous system in the model planarian Schmidtea mediterranea: an immunocytochemical study. Neurosci Res. 61:375-84.

CHATZAKI E, CROWE PD, WANG L, MILLION M, TACHÉ Y, GRIGORIADIS DE (2004). CRF receptor type 1 and 2 expression and anatomical distribution in the rat colon. J Neurochem 90:309-316. 
COLLINS JJ, HOU X, ROMANOVA EV, LAMBRUS BG, MILLER CM, SABERI A, SWEEDLER JV, NEWMARK PA (2010). Genome-wide analyses reveal a role for peptide hormones in planarian germline development. PLOS Biol. 8:e1000509.

EISENHOFFER GT, KANG H, SÁNCHEZ ALVARADO A (2008). Molecular analysis of stem cells and their descendants during cell turnover and regeneration in the planarian Schmidtea mediterranea. Cell Stem Cell 3: 327-339.

FERNANDÉZ-TABOADA E, MORITZ S, ZEUSCHNER D, STEHLING M, SCHÖLER HR, SALÓ E, GENTILE L (2010). Smed-SmB, a member of the LSm protein superfamily, is essential for chromatoid body organization and planarian stem cell proliferation. Development 137:1055-1065.

FERNANDÉZ-TABOADA E, RODRÍGUEZ-ESTEBAN G, SALÓ E, ABRIL JF (2011). A proteomics approach to decipher the molecular nature of planarian stem cells. BMC Genomics 12: 133.

FRANQUINETR (1979). The role of serotonin and catecholamines in the regeneration of the planaria Polycelis tenvis. J Embryol Exp Morphol 51: 85-95.

FRIEDEL T, WEBB RA (1979). Stimulation of mitosis in Dugesia tigrina by a neurosecretory fraction. Can J Zool 57: 1818-1819.

GENTILE L, CEBRIÀ F, BARTSCHERER K (2011). The planarian flatworm: an in vivo model for stem cell biology and nervous system regeneration. Dis Model Mech 4:12-19.

GUO T, PETERS AH, NEWMARK, PA (2006). A Bruno-like gene is required for stem cell maintenance in planarians. Dev Cell 11: 159-169.

HAYASHI T, ASAMI M, HIGUCHI S, SHIBATA N, AGATA (2006). Isolation of planarian X-ray-sensitive stem cells by fluorescence-activated cell sorting. Dev Growth Differ 48: 371-380.

HIGUCHI S, HAYASHI T, HORI I, SHIBATA N, SAKAMOTO H, AGATA K (2007). Characterization and categorization of fluorescence activated cell sorted planarian stem cells by ultrastructural analysis. Dev Growth Differ 49: 571-581.

HONG HS, KIM DO Y, YOON KJ, SON Y (2011). A new paradigm for stem cell therapy: substance-P as a stem cell-stimulating agent. Arch Pharm Res. 34: 2003-2006.

HORI I, KISHIDA Y (2003). Quantitative changes in nuclear pores and chromatoid bodies induced by neuropeptides during cell differentiation in the planarian Dugesia japonica. J Submicrosc Cytol Pathol. 35:439-444.

HAYASHIT, SHIBATAN, OKUMURAR, KUDOMET, NISHIMURAO, TARUI H, AGATA $K$ (2010). Single-cell gene profiling of planarian stem cells using fluorescent activated cell sorting and its "index sorting" function for stem cell research. Dev Growth Differ 52: 131-144.

KALINKOVICHA, SPIEGELA, SHIVTIELS, KOLLETO, JORDANEY N, PIACIBELLO W, LAPIDOT T (2009). Blood-forming stem cells are nervous: direct and indirect regulation of immature human CD34+ cells by the nervous system. Brain Behav Immun 23:1059-1065.

KATAYAMA Y, BATTISTA M, KAO WM, HIDALGO A, PEIRED AJ, THOMAS SA, FRENETTE PS (2006). Signals from the sympathetic nervous system regulate hematopoietic stem cell egress from bone marrow. Cell 124:407-421.

KOBAYASHI C, SAITO Y, OGAWAA K, AGATA K (2007). Wnt signaling is required for antero-posterior patterning of the planarian brain. Dev Biol 306: 714-724.

KOLLET O, CANAANI J, KALINKOVICH A, LAPIDOT T (2012). Regulatory cross talks of bone cells, hematopoietic stem cells and the nervous system maintain hematopoiesis. Inflamm Allergy Drug Targets [Epub ahead of print].

KRESHCHENKO ND, SEDELNIKOV Z, SHEIMAN IM, REUTER M, MAULEAG, AND GUSTAFSSON MK (2008). Effects of neuropeptide F on regeneration in Girardia tigrina (Platyhelminthes). Cell Tissue Res 331:739-750.

KWINTER DM, LO K, MAFI P, SILVERMAN MA. (2009). Dynactin regulates bidirectional transport of dense-core vesicles in the axon and dendrites of cultured hippocampal neurons. Neuroscience 162: 1001-1010.

KUMAR A, GODWIN JW, GATES PB, GARZA-GARCIA AA, BROCKES JP (2007). Molecular Basis for the nerve dependence of limb regeneration in an adult vertebrate. Science 318: 772-778.

LAPIDOT T, KOLLET O (2010). The brain-bone-blood triad: traffic lights for stem-cell homing and mobilization. Hematology Am Soc Hematol Educ Program 2010: 1-6.

LI X, SERWANSKI DR, MIRALLES CP, NAGATA K, DE BLAS AL (2009). Septin 11 is present in GABAergic synapses and plays a functional role in the cytoarchitecture of neurons and GABAergic synaptic connectivity. J Biol 284: 17253-17265.

LUNDGREN O, JODAL M, JANSSON M, RYBERG AT, SVENSSON L (2011). Intestinal epithelial stem/progenitor cells are controlled by mucosal afferent nerves. PLOS ONE 6: e16295.
MÉNDEZ-FERRER S, LUCAS D, BATTISTAM, FRENETTE PS (2008). Haematopoietic stem cell release is regulated by circadian oscillations. Nature 452:442-447.

NEWMARK PA, SÁNCHEZ ALVARADO A (2000). Bromodeoxyuridine specifically labels the regenerative stem cells of planarians. Dev Biol 220:142-153.

NISHIMURA K, KITAMURA Y, INOUE T, UMESONO Y, YOSHIMOTO K, TAKEUCHI K, TANIGUCHI T, AGATAK $(2007$, a). Identification and distribution of tryptophan hydroxylase (TPH)-positive neurons in the planarian Dugesia japonica. Neurosci Res. 59:101-116.

NISHIMURA K, KITAMURA Y, INOUE T, UMESONO Y, SANO S, YOSHIMOTO K, INDEN M, TAKATA K, TANIGUCHI T, SHIMOHAMA S, AGATA K (2007, b). Reconstruction of dopaminergic neural network and locomotion function in planarian regenerates. Dev Neurobiol. 67:1059-1078.

NISHIMURA K, KITAMURA Y, INOUE T, UMESONO Y, YOSHIMOTO K, TANIGUCHI T, AGATA K (2008a). Characterization of tyramine beta-hydroxylase in planarian Dugesia japonica: cloning and expression. Neurochem Int. 53:184-192.

NISHIMURA K, KITAMURA Y, UMESONO Y, TAKEUCHI K, TAKATA K, TANIGUCHI T, AGATA K (2008b). Identification of glutamic acid decarboxylase gene and distribution of GABAergic nervous system in the planarian Dugesia japonica. Neuroscience 153:1103-1114.

ORII H, SAKURAI T, WATANABE K (2005). Distribution of the stem cells (neoblasts) in the planarian Dugesia japonica. Dev Genes Evol. 215: 143-157.

OVIEDO NJ, LEVIN M (2007). Smedinx-11 is a planarian stem cell gap junction gene required for regeneration and homeostasis. Development 134: 3121-3131.

QIN YF, FANG HM, TIAN QN, BAO ZX, LU P, ZHAO JM, MAI J, ZHU ZY, SHU LL, ZHAO L, CHEN SJ, LIANG F, ZHANG YZ, ZHANG ST (2011). Transcriptome profiling and digital gene expression by deep-sequencing in normal/regenerative tissues of planarian Dugesia japonica. Genomics 97: 364-371.

RANDOLPHH (1892). The regeneration of the tail in lumbriculus. J. Morphol.7:317-344.

REDDIENPW, BERMANGEA, MURFITTK, JENNINGS JAND SÁNCHEZALVARADO $A$ (2005). Identification of genes needed for regeneration, stem cell function, and tissue homeostasis by systematic perturbation in planarians. Developmental Cell 8: 635-649.

ROSSI L, SALVETTI A, LENA A, BATISTONI R, DERI P, PUGLIESI C, LORETI E, GREMIGNI V (2006). Djpiwi-1, a member of the paz-piwi gene family, defines a subpopulation of planarian stem cells. Dev Genes Evol 216: 335-346.

ROSSI L, SALVETTI A, MARINCOLA FM, LENAA, DERI P, MANNINI L, BATISTONI R, WANG E, GREMIGNI V (2007). Deciphering the molecular machinery of stem cells: a look at the neoblast gene expression profile. Genome Biol. 8:R62.

ROSSI L, SALVETTI A, BATISTONI R, DERI P, GREMIGNI V (2008). Planarians, a tale of stem cells. Cell Mol Life Sci 65: 16-23.

ROUHANA L, SHIBATA N, NISHIMURA O, AGATA K (2010). Different requirements for conserved post-transcriptional regulators in planarian regeneration and stem cell maintenance. Dev Biol 341: 429-443.

SALÓ E, ABRIL JF, ADELL T, CEBRIÀ F, ECKELT K, FERNANDEZ-TABOADA E, HANDBERG-THORSAGER M, IGLESIAS M, MOLINA MD, RODRÍGUEZESTEBAN G (2009). Planarian regeneration: achievements and future directions after 20 years of research. Int $J$ Dev Biol 53: 1317-1327.

SALVETTI A, ROSSI L, DERI P, BATISTONI R (2000). An MCM2-related gene is expressed in proliferating cells of intact and regenerating planarians. Dev Dyn 218: 603-614

SALVETTI A, ROSSI L, LENA A, BATISTONI R, DERI P, RAINALDI G, LOCCI MT, EVANGELISTAM, GREMIGNIV (2005). Djpum, a homologue of Drosophila Pumilio, is essential to planarian stem cell maintenance. Development 132: 1863-1874.

SALVETTIA, ROSSI L, BONUCCELLI L, LENAA, PUGLIESI C, RAINALDI G, EVANGELISTAM, GREMIGNIV (2009). Adult stem cell plasticity: neoblast repopulation in non-lethally irradiated planarians. Dev Biol 328: 305-314.

SÁNCHEZ ALVARADO A (2007). Stem cells and the planarian Schmidtea mediterranea. C R Biol 330: 498-503.

SATO K, SHIBATA N, ORII H, AMIKURA R, SAKURAI T, AGATA K, KOBAYASHI $S$, WATANABE K (2006). Identification and origin of the germline stem cells as revealed by the expression of nanos-related gene in planarians. Dev Growth Differ 48:615-628.

SCADDENDT (2006). The stem-cell niche as an entity of action. Nature441: 1075-1079.

SCIMONE ML, MEISEL J, REDDIEN PW (2010). The Mi-2-like Smed-CHD4 gene is required for stem cell differentiation in the planarian Schmidtea mediterranea. 


\section{L. Rossi et al.}

Development 137: 1231-1241.

SHIBATA N, UMESONO Y, ORII H, SAKURAI T, WATANABE K, AGATA K (1999). Expression of vasa(vas)-related genes in germline cells and totipotent somatic stem cells of planarians. Dev Biol 206:73-87.

SHIBATA N, ROUHANA L, AGATA K (2010). Cellular and molecular dissection of pluripotent adult somatic stem cells in planarians. Dev Growth Differ 52: 27-41.

SOLANAJ, LASKO P, ROMERO R (2009). Spoltud- 1 is a chromatoid body component required for planarian long-term stem cell self-renewal. Dev Biol 328: 410-421.

SPIEGEL A, KALINKOVICH A, SHIVTIEL S, KOLLET O, LAPIDOT T (2008). Stem cell regulation via dynamic interactions of the nervous and immune systems with the microenvironment. Cell Stem Cell 3: 484-492

WAGNERDE, WANG IE, REDDIEN PW (2011). Clonogenic neoblasts are pluripotent adult stem cells that underlie planarian regeneration. Science 332: 811-816.

WANG D, ZHANG L, ZHAO G, WAHLSTRÖM G, HEINO TI, CHEN J, ZHANG YQ (2010). Drosophilatwinfilin is required for cell migration and synaptic endocytosis. J Cell Sci 123: 1546-1556.
WENEMOSER D, REDDIEN PW (2010). Planarian regeneration involves distinct stem cell responses to wounds and tissue absence. Dev Biol. 344: 979-991.

WINGE I, MCKINNEY JA, YING M, D'SANTOS CS, KLEPPE R, KNAPPSKOG PM, HAAVIK J (2008). Activation and stabilization of human tryptophan hydroxylase 2 by phosphorylation and 14-3-3 binding. Biochem $J$ 410: 195-204.

YAGER J, RICHARDS S, HEKMAT-SCAFE DS, HURD DD, SUNDARESAN V, CAPRETTE DR, SAXTON WM, CARLSON JR, STERN M (2001). Control of Drosophila perineurial glial growth by interacting neurotransmitter-mediated signaling pathways. Proc Natl Acad Sci USA 98: 10445-10450.

YOSHIDA-KASHIKAWA, M., SHIBATA, N., TAKECHI, K. AND AGATA, K (2007). DjCBC-1, a conserved DEAD box RNA helicase of the RCK/p54/Me31B family, is a component of RNA-protein complexes in planarian stem cells and neurons. Dev Dyn 236: 3436-3450.

YOUSEF GM, KISHI T, DIAMANDIS EP (2003). Role of kallikrein enzymes in the central nervous system. Clin Chim Acta 329: 1-8. 


\section{Further Related Reading, published previously in the Int. J. Dev. Biol.}

The roles of BMP and IL-3 signaling pathways in the control of hematopoietic stem cells in the mouse embryo.

Catherine Robin and Charles Durand

Int. J. Dev. Biol. (2010) 54: 1189-1200

Planarian regeneration: achievements and future directions after 20 years of research Emili Saló, Josep F. Abril, Teresa Adell, Francesc Cebriá, Kay Eckelt, Enrique FernándezTaboada, Mette Handberg-Thorsager, Marta Iglesias, M Dolores Molina and Gustavo Rodríguez-Esteban

Int. J. Dev. Biol. (2009) 53: 1317-1327

From Planarians to Mammals - the many faces of regeneration Jerzy Moraczewski, Karolina Archacka, Edyta Brzoska, Maria-Anna Ciemerych, Iwona Grabowska, Katarzyna Janczyk-Ilach, Wladyslawa Streminska and Malgorzata Zimowska Int. J. Dev. Biol. (2008) 52: 219-227

Expression of DjXnp, a novel member of the SNF2-like ATP-dependent chromatin remodelling genes, in intact and regenerating planarians

Leonardo Rossi, Paolo Deri, Ilaria Andreoli, Vittorio Gremigni, Alessandra Salvetti and Renata Batistoni

Int. J. Dev. Biol. (2003) 47: 293-298

Effects of activators and antagonists of the neuropeptides substance $P$ and substance $\mathrm{K}$ on cell proliferation in planarians

J Baguñà, E Saló and R Romero

Int. J. Dev. Biol. (1989) 33: 261-266

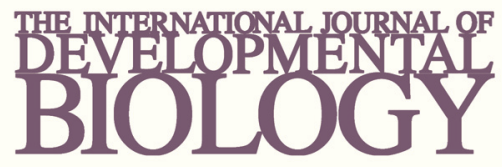

Volume 54 Nos. 6/7
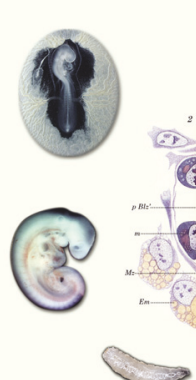

Developmental Hematopoiesis
Special Issue
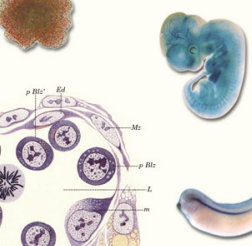

(1)
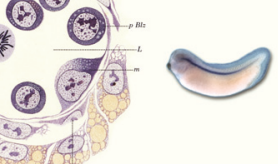

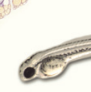

ing
5 yr ISI Impact Factor $(2010)=2.961$

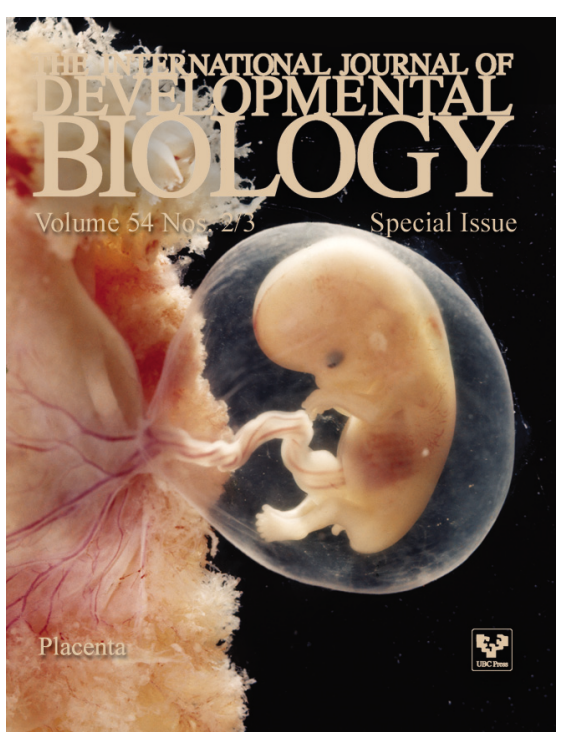

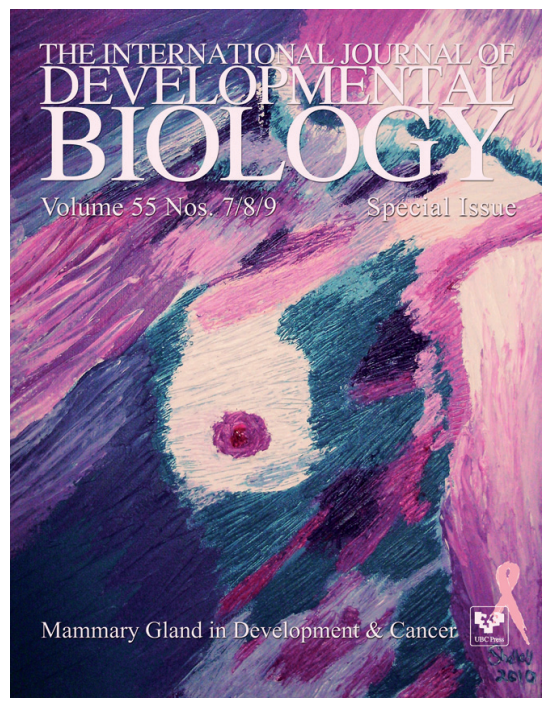

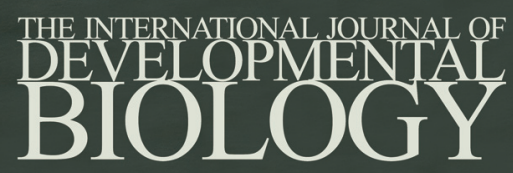

Volume 55 Nos. $4 / 5$

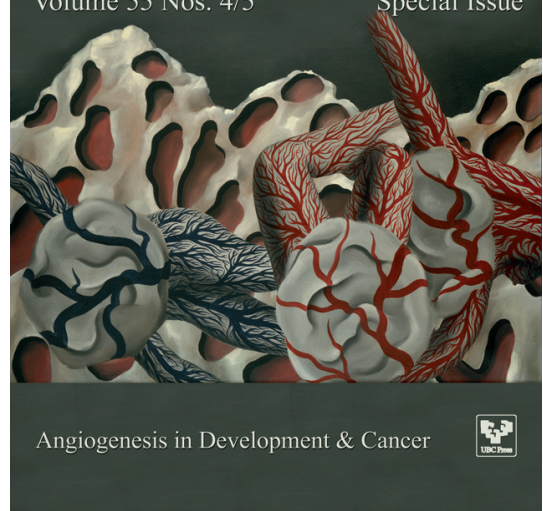

